Vol. 4, n $1 \mid 2000$

Varia

\title{
Martin Rubin, Thrillers
}

Cambridge : Cambridge University Press, 1999, xiv +319 p., 70 b\&w

illustrations, ISBN-0-521-58183 4 (hb), 0-521-58839-1 (pb)

James Chapman

\section{(2) OpenEdition}

1 Journals

Electronic version

URL: https://journals.openedition.org/chs/882

DOI: $10.4000 /$ chs. 882

ISSN: 1663-4837

Publisher

Librairie Droz

Printed version

Date of publication: 1 January 2000

Number of pages: 144-146

ISBN: 2-600-00433-5

ISSN: $1422-0857$

\section{Electronic reference}

James Chapman, "Martin Rubin, Thrillers", Crime, Histoire \& Sociétés / Crime, History \& Societies [Online], Vol. 4, $n^{\circ} 1$ | 2000, Online since 02 April 2009, connection on 23 March 2022. URL: http://

journals.openedition.org/chs/882 ; DOI: https://doi.org/10.4000/chs.882 
of areas of research which otherwise would remain elusive, or whose very existence might be only very imperfectly grasped. Legal records survive in bulk (frightening bulk in the English case), and many court archives have as yet only barely been investigated. But as the authors of the papers collected here remind us, if these records are approached with the appropriate mixture of caution and imagination, exciting new perspectives can be opened up on the past.

\author{
J.A. Sharpe \\ (University of York, England) \\ jas@york.ac.uk
}

\title{
Martin Rubin, Thrillers, Cambridge : Cambridge University Press, 1999, xiv + 319 p., 70 b\&w illustrations, ISBN-0-521-58183 4 (hb), 0-521-58839-1 (pb).
}

This book is the first in a new series from Cambridge University Press entitled Genres in American Cinema (general editor: Barry Keith Grant). The thriller has been a much-neglected genre in film studies (less so in literature), so any new work in this field is to be welcomed. Martin Rubin has successfully fulfilled the series' aim of providing « a comprehensive account of its genre... balancing theoretical and historical discussion with close readings of representative films» (p. iii). Yet in certain respects, the subject seems an unusual choice with which to begin this series. Firstly, the thriller is a notoriously difficult genre to define, encompassing as it does crime films, gangster films, police and private-eye films, spy films and horror films. As the author himself points out: "The very breadth and vagueness of the thriller category understandably discourages efforts to define it precisely » (p. 13). And secondly, unlike certain movie genres such as the western or the musical, there is nothing uniquely American about the thriller, a genre which can be identified in most national cinemas and which is especially conducive to international cross-fertilisation.

Rubin's solution to the first of these problems is to take the broadest possible understanding of what constitutes a thriller: «The thriller can be conceptualised as a 'metagenre' that gathers several other genres under its umbrella, and as a band in the spectrum that colors each of those particular genres » (p.4). Thus he casts his net widely to include films that might seem tangential to the thriller, including early chase films such as Edwin S. Porter's The Great Train Robbery (1903) and the lesser-known Capture of «Yegg» Bank Burglars (1904), the suspense melodramas of D. W. Griffith such as The Lonedale Operator (1911) and The Girl and Her Trust (1912), and the "comedy of thrills " exhibited in the films of Harold Lloyd, such as Girl Shy (1924) and Speedy (1928). What these films share in common is a sense of visceral pleasure and edge-of-your-seat suspense which Rubin identifies as a key ingredient of the thriller. Rubin's «metagenre » also extends the boundaries of the thriller to include the horror film (which most film historians regard as a genre in its own right), thus warranting the inclusion of the classic monster films of the 1930s he identifies Mystery of the Wax Museum (1933) as a significant film which links the European Gothic of the Dracula and Frankenstein cycles to the modem urban melodrama of the American newspaperreporter film - and more recent manifestations of American horror in the «splatter» and «stalker» films which have proliferated since the 1970s. 
The second problem - the international influences on the thriller - are addressed by the simple expedient of ranging beyond Hollywood alone. Given the nature of the thriller, it would be disingenuous to do otherwise. Indeed, as Rubin shows, one of the most important influences on the thriller was the cinema of German Expressionism in the years following the First World War. «Expressionism emphasized specific visual codes that would be recycled throughout the history of the thriller, most obviously in film noir » (p. 65). The history of the thriller is charted through such landmarks as Alfred Hitchcock's British spy thrillers of the 1930s (The Man Who Knew Too Much, The 39 Steps, Secret Agent [sic], Sabotage and The Lady Vanishes) and even extends to the French nouvelle vague (the small-time gangsters of Godard's A bout de souffle/ Breathless and Truffaut's Tirez sur le pianiste/Shoot the Piano Player), thus ranging wider than the series title, Genres in American Cinema, suggests.

The book is divided into three sections. Rubin first considers critical and theoretical writing on the thriller, drawn mainly from literary studies. From G.K. Chesterton he extracts the notion that the setting of the thriller is essentially modem and urban; from W.H. Matthews he borrows the notion of mazes and labyrinths as metaphors for the processes of story-telling in the thriller; and from Pascal Bonitzer he adopts the idea of «partial vision» that determines the nature of filmic suspense (which, as Hitchcock realised, so often depends on the audience being aware of things that characters in the film are not). The second, most substantive section is an overview of the history of the thriller, which Rubin divides into three periods: a «formative period» froin the early days of cinema to the 1930s, a «classical period» covering the 1940s and 1950s, and a 'modern period' from the 1960s to the present. Although the emphasis is on genre, there are discernible traces of auteurism as Rubin identifies two particular directors - Alfred Hitchcock and Fritz Lang - who between them were most significant in the evolution of the film thriller. The third section comprises close analyses of five films chosen to represent diffrent types of thriller. Thus the detective thriller is exemplified by case studies of The Kennel Murder Case (1933) and The Big Sleep (1946) - the former representing the classical detective story (or «whodunit»), the latter representing the «hard-boiled» variant - the psychological crime thriller by Hitchcock's Strangers on a Train (1941), the spy thriller by Lang's Man Hunt (1941), and the police thriller by The French Connection (1971).

Both the historical overview and the case studies are written with admirable clarity, with Rubin discussing his examples both in terms of film style and in relation to the wider social context. There are matters of interpretation over which one could quibble. Admittedly I have a vested interest here, but I felt that the discussion of the James Bond films of the 1960s rather missed the point about their importance within the thriller genre, representing as they did both the last of the thick-ear imperialist spy thrillers in the Bulldog Drummond tradition and the first of the high-tech action movies that have now become one of the mainstream Hollywood genres (exemplified by the Lethal Weapon and Die Hard movies and their like). I would also question whether Rubin's insistence on the urban location of the thriller is entirely appropriate given the range of examples which he chooses. While the mean streets' of American cities provide the metaphysical landscape for film noir, other types of thriller have indicated a trend away from cities and into the wide open spaces of the countryside. The rationale behind the famous sequence in North by Northwest (1959) where Cary Grant is attacked by a crop-dusting plane on a 
Mid-Western prairie was precisely because Hitchcock wanted to get away from the cliche of « a dark night at a narrow intersection of the city. The waiting victim standing in a pool of light under a street lamp " (quoted in François Truffaut, Hitchcock, London, Paladin, 1986 rev.edn, p.392). Moreover, as Carol J. Clover has shown, the countryside is represented as a terrifying "other» space in films such as The Texas Chain Saw Massacre (1974) and I Spit On Your Grave (1977), which are structured around a city/country, modern/backward axis (Men, Women and Chain Saws: Gender in the Modern Horror Film, London, British Film Institute, 1992).

Rubin concludes that the appeal of the thriller for audiences is to be found in «its grip on our ambivalent desires both to escape from and to remain within the uneasy security of our increasingly downsized world » (p.268). The thriller revolves around a tension between «familiar routine and exotic adventure». The films of Hitchcock and others open up the «chaos world »: the idea that the forces of anarchy may erupt at any moment from beneath the apparent normality of everyday life. For all that the detective story, especially, has sometimes been used as a vehicle to explore social problems, in which the figure of the detective acts as a sort of moral conscience figure, the subject matter of the thriller is sensational, not realistic. Crime and its effects are rarely treated in a psychologically realistic manner, except perhaps in semi-documentary films such as Call Northside 777 (1947) and The Naked City (1948). The thriller may take as its subject matter society's ills, but it does not offer a solution. As Rubin recognises, audiences do not watch thrillers to resolve their own problems, they just go along for the ride.

James Chapman

The Open University (U.K.) 